\title{
Combined In Situ XAFS/DRIFTS Studies of the Evolution of Nanoparticle Structures from Molecular Precursors
}

\author{
Ellie K. Dann, ${ }^{\dagger,}$ Emma K. Gibson, ${ }^{\dagger \dagger}$ Richard A. Catlow, ${ }^{\dagger,}, \S$ Paul Collier, ${ }^{\perp}$ Tugce Eralp Erden, ${ }^{\perp}$
}

Diego Gianolio, ${ }^{\text {"L }}$ Christopher Hardacre, ${ }^{\ddagger} \square$ (৫) Anna Kroner, ${ }^{\text {II }}$ Agnes Raj, ${ }^{\perp}$ Alexandre Goguet, ${ }^{*}$ and Peter P. Wells*, $*, \mathbb{I}, \bigcirc$

${ }^{\dagger}$ Department of Chemistry, University College London, 20 Gordon Street, London WC1H 0AJ, United Kingdom

${ }^{\ddagger}$ UK Catalysis Hub, Research Complex at Harwell, Rutherford Appleton Laboratory, Harwell Oxon, Didcot OX11 0FA, United Kingdom

${ }^{\S}$ Cardiff Catalysis Institute, School of Chemistry, Cardiff University, Main Building, Park Place, Cardiff CF10 3AT, United Kingdom

${ }^{\perp}$ Johnson Matthey Technology Centre, Blounts Court Road, Sonning Common, Reading RG4 9NH, United Kingdom

IIDiamond Light Source Ltd., Harwell Science and Innovation Campus, Chilton, Didcot OX11 0DE, United Kingdom

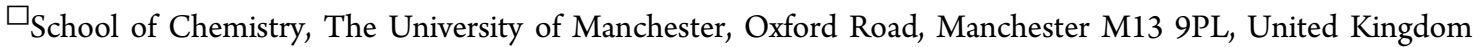

- School of Chemistry, Queen's University Belfast, David Keir Building, Stranmillis Road, Belfast BT9 5AG, United Kingdom

${ }^{\circ}$ School of Chemistry, University of Southampton, University Road, Southampton SO17 1BJ, United Kingdom

\section{Supporting Information}

\begin{abstract}
The rational design of catalyst materials is of great industrial significance, yet there is a fundamental lack of knowledge in some of the most well-established processes, e.g. formation of supported nanoparticle structures through impregnation. Here, the choice of precursor has a significant influence on the resulting catalytic properties of the end material, yet the chemistry that governs the transformation from defined molecular systems to dispersed nanoparticles is often overlooked. A spectroscopic method for advanced in situ characterization is employed to capture the formation of $\mathrm{PdO}$ nanoparticles supported on $\gamma-\mathrm{Al}_{2} \mathrm{O}_{3}$ from two alternative molecular precursors - $\mathrm{Pd}\left(\mathrm{NO}_{3}\right)_{2}$ and $\mathrm{Pd}\left(\mathrm{NH}_{3}\right)_{4}(\mathrm{OH})_{2}$. Time-resolved diffuse reflectance infrared Fourier transform spectroscopy is able to identify the temperature assisted pathway for

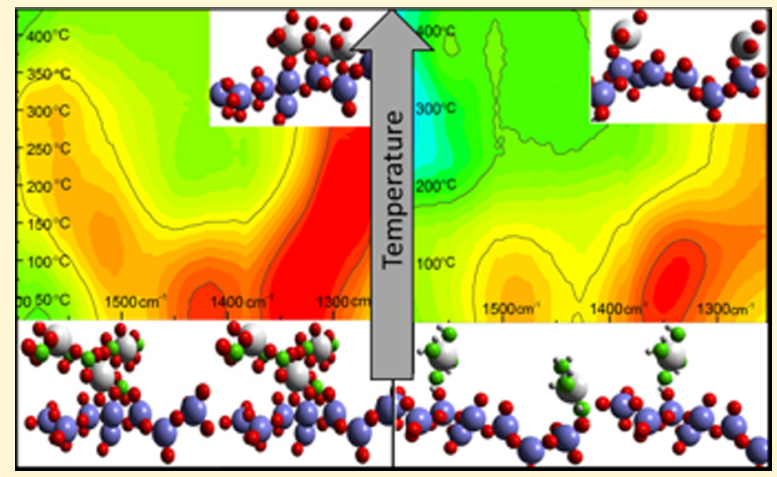
ligand decomposition, showing that $\mathrm{NH}_{3}$ ligands are oxidized to $\mathrm{N}_{2} \mathrm{O}$ and $\mathrm{NO}^{-}$species, whereas $\mathrm{NO}_{3}{ }^{-}$ligands assist in joining Pd centers via bidentate bridging coordination. Combining with simultaneous X-ray absorption fine structure spectroscopy, the resulting nucleation and growth mechanisms of the precious metal oxide nanoparticles are resolved. The bridging ability of palladium nitrate aids formation and growth of larger PdO nanoparticles at lower onset temperature $\left(<250{ }^{\circ} \mathrm{C}\right)$. Conversely, impregnation from $\left[\mathrm{Pd}\left(\mathrm{NH}_{3}\right)_{4}\right]^{2+}$ results in well-isolated Pd centers anchored to the support which requires a higher temperature $\left(>360^{\circ} \mathrm{C}\right.$ ) for migration to form observable $\mathrm{Pd}-\mathrm{Pd}$ distances of $\mathrm{PdO}$ nanoparticles. These smaller nanoparticles have improved dispersion and an increased number of step and edge sites compared to those formed from the conventional $\mathrm{Pd}\left(\mathrm{NO}_{3}\right)_{2}$ salt, favoring a lower light off temperature for complete methane oxidation.
\end{abstract}

\section{INTRODUCTION}

Supported metal nanoparticles are a cornerstone of heterogeneous catalysis, and by extension, the chemical industry. Optimizing the preparation method for smaller nanoparticle size and improved dispersion is a common theme in heterogeneous catalyst design: to improve specific surface area, lower precious metal content, and increase metal-support interfacial regions while maintaining thermostability toward sintering. There are various methods for the preparation of supported metal catalysts such as controlled colloidal routes, ${ }^{1,2}$ deposition precipitation, ${ }^{3}$ grafting techniques, ${ }^{4}$ and atomic deposition, all of which result in nanoparticle materials with differing properties. Despite these efforts, the conventional route of incipient wetness impregnation is regarded as a reliable route, taking advantage of accessible precursor materials (inorganic metal salt) in a one-step batch process that can be scaled up for industrial production. ${ }^{5}$

Adjustments to the impregnation method by using alternative metal precursors result in differing properties of the final nanoparticle catalyst together with any changes to

Received: June 20, 2017

Revised: July 21, 2017

Published: July 25, 2017 
temperature and atmospheric conditions of the proceeding drying and calcination steps. ${ }^{6,7}$ The amphoteric nature of common metal oxide supports means that the $\mathrm{pH}$ of the impregnating solution is an important factor. Charged surface sites (e.g., $\mathrm{Al}-\mathrm{O}^{-}$or $\mathrm{Al}-\mathrm{OH}^{+}$) can be created when the $\mathrm{pH}$ is above or below the isoelectric point of the support, which allow the impregnation of metal salts to occur via ion exchange or ligand substitution mechanisms. ${ }^{8}$ Nanoparticles prepared from chloride containing precursors are found to suffer from residual $\mathrm{Cl}^{-}$blocking surface catalytic sites, ${ }^{9-11}$ whereas organic precursors such as acetate or acetylacetonate as well as ammonia containing salts and nitrate precursors have been reported to yield greater dispersion over the support. ${ }^{6,9,12}$ Despite investigations into the influence of preparation methods on the final metal dispersion and catalytic activity, ${ }^{7,13}$ there is often lack of evidence and reasoning for the chemical processes that govern the nanoparticle formation.

In this study, genesis of $\mathrm{PdO}$ nanoparticles from two different impregnated $\mathrm{Pd}$ precursors, $\mathrm{Pd}\left(\mathrm{NO}_{3}\right)_{2}$ and $\mathrm{Pd}$ $\left(\mathrm{NH}_{3}\right)_{4}(\mathrm{OH})_{2}$, are investigated. The development of $\mathrm{PdO}$ nanoparticles on high surface area $\gamma-\mathrm{Al}_{2} \mathrm{O}_{3}$ has been studied extensively for a number of catalytic applications: $\mathrm{CO}$ oxidation, ${ }^{14} \mathrm{H}_{2} \mathrm{O}_{2}$ synthesis, ${ }^{15}$ upgrading bio-oils, ${ }^{16}$ and automotive three-way catalysts. ${ }^{17}$ Of recent industrial interest is the use of $\mathrm{Pd} / \gamma-\mathrm{Al}_{2} \mathrm{O}_{3}$ in catalyzing low temperature methane oxidation for the clean and efficient operation of compressed natural gas engines (CNGs). ${ }^{18-21}$ Mechanistic studies propose the oxidation of $\mathrm{CH}_{4}$ to occur on a reducible $\mathrm{PdO}$ nanoparticle surface, close to the $\mathrm{Al}_{2} \mathrm{O}_{3}$ interface where oxygen migration from the support can assist in reoxidation of the $\mathrm{Pd}$ nanoparticle surface via a Mars-Van Krevelen mechanism. ${ }^{21}$ Therefore, the preparation of $\mathrm{Pd} / \gamma-\mathrm{Al}_{2} \mathrm{O}_{3}$ with greatest dispersion of $\mathrm{PdO}$ for increased interfacial contact with the support is most desirable.

The advantage of synchrotron-based techniques applied to investigate industrial catalyst preparation is highlighted in work by Espinosa-Alonso et al. for the formation of supported $\mathrm{Ni}$ materials. ${ }^{22}$ In this study, by combining two noninvasive, timeresolved spectroscopic techniques, the surface and bulk properties of the precursor materials are probed in situ under a controlled calcination environment. While diffuse reflectance infrared Fourier transform spectroscopy (DRIFTS) is used to follow the vibrational modes of adsorbed and coordinated inorganic molecular species at the surface, X-ray absorption fine structure (XAFS) is used to follow the local coordination environment and oxidation state of Pd throughout the bulk of the sample. Using both techniques at the same time with online mass spectrometry of the effluent gas gives the advantage of confidently assigning features that change with response to sample environment and allow interpretation of the mechanisms involved in ligand decomposition and metal nanoparticle formation.

\section{EXPERIMENTAL SECTION}

Sample Preparation. Two 3 wt $\% \mathrm{Pd} / \gamma-\mathrm{Al}_{2} \mathrm{O}_{3}$ catalysts were prepared by incipient wetness impregnation of an aqueous solution of Pd salt onto a $\gamma-\mathrm{Al}_{2} \mathrm{O}_{3}$ support (SASOL), followed by calcination (500 ${ }^{\circ} \mathrm{C}, 2 \mathrm{~h}$ ). The first sample was prepared from an acidified aqueous solution of palladium nitrate ( 15.11 wt \% Pd, Johnson Matthey) and a defined quantity of $\mathrm{HNO}_{3}$, corresponding to a molecular ratio $\mathrm{NO}_{3}^{-} /$ $\mathrm{Pd}=3.8$. The second sample was prepared from an aqueous solution of tetraamminepalladium(II) hydroxide (5.96 wt \% Pd, Johnson Matthey), prepared by dissolution of tetraamminepalladium hydrogen carbonate (Johnson Matthey, 99.99\%) in aqueous $\mathrm{NH}_{4} \mathrm{OH}$ solution
(28 wt \%). Incipient wetness impregnations were realized at room temperature with calculated quantities of respective aqueous $\mathrm{Pd}$ solutions to obtain $3 \mathrm{wt} \% \mathrm{Pd}$ catalysts. The impregnated precursor catalyst samples $\mathrm{Pd}\left(\mathrm{NO}_{3}\right)_{2} / \gamma-\mathrm{Al}_{2} \mathrm{O}_{3}$ and $\mathrm{Pd}\left(\mathrm{NH}_{3}\right)_{4}(\mathrm{OH})_{2} / \gamma-\mathrm{Al}_{2} \mathrm{O}_{3}$ were subsequently dried at $100{ }^{\circ} \mathrm{C}$ overnight.

In Situ XAFS/DRIFTS Measurements. In situ XAFS and DRIFTS measurements were conducted at B18, Diamond Light Source, Didcot, UK of the impregnated, dried precursor samples during the calcination procedure using the modified Harrick DRIFTS cell. A DaVinci arm fitted with praying mantis optics was used to refocus the IR beam outside the FTIR spectrometer for positioning of the Harrick DRIFTS cell in the X-ray beam. The Harrick XAFS/DRIFTS cell, which has been used and reported previously, ${ }^{23}$ has an X-ray path length of 3.17 $\mathrm{mm}$ positioned $1.04 \mathrm{~mm}$ below the surface of the catalyst bed. The sample was heated to $500{ }^{\circ} \mathrm{C}\left(10{ }^{\circ} \mathrm{C} \mathrm{min}{ }^{-1}\right.$ under a constant controlled flow of air $\left(30 \mathrm{~mL} \mathrm{~min}^{-1}\right)$ and maintained at $500^{\circ} \mathrm{C}$ for a 2 $\mathrm{h}$ dwell period before being cooled back to room temperature. XAFS and DRIFTS spectra were recorded continuously throughout this period, and the effluent gas was monitored online by a Hiden QGA mass spectrometer. XAFS measurements were performed at the Pd $K$ edge in transmission mode using QEXAFS setup with a fast scanning $\mathrm{Si}(311)$ double crystal monochromator. All XAFS spectra were acquired with a $\mathrm{Pd}$ foil placed between $I_{\mathrm{t}}$ and $I_{\mathrm{ref}}$ and the time resolution was $21 \mathrm{~s}$ spectrum ${ }^{-1}\left(k_{\max }=15.9\right)$. DRIFTS spectra were collected with an Agilent Carey 680 FTIR spectrometer taking 64 scans with a resolution of $4 \mathrm{~cm}^{-1}$ using the liquid nitrogen cooled MCT detector. The time resolution of DRIFTS was $30 \mathrm{~s} \mathrm{spectrum}^{-1}$.

EXAFS Analysis. Processing extended X-ray absorption fine structure (EXAFS) data was performed using IFEFFIT with the Horae package (Athena and Artemis). Athena was used to calibrate, align, and normalize the spectra with respect to the Pd foil, for which $E_{0}$ was set at $24358 \mathrm{eV}$. EXAFS data processing of $k^{2}$ data used an appropriate $k$ range for the data $\left(3.2-13.4 \AA^{-1}\right)$. Analysis of the Fourier transformed data was limited to fitting with the first two coordination shells (denoted $\mathrm{Pd}_{(\mathrm{O}) 1}, \mathrm{Pd}_{(\mathrm{O}) 2}, \mathrm{Pd}_{(\mathrm{N}) 1}, \mathrm{Pd}_{(\mathrm{N}) 2}, \mathrm{Pd}_{(\mathrm{Pd}) 1}$, and $\left.\mathrm{Pd}_{(\mathrm{Pd}) 2}\right)$, using cif files of $\mathrm{Pd}\left(\mathrm{NO}_{3}\right)_{2}$ and $\mathrm{PdO}$. The amplitude reduction factor, $S_{0}{ }^{2}$, was derived from fitting the $\mathrm{Pd}$ foil using a coordination number of 12 to give a value of 0.8 . The value of $\sigma^{2}$, the mean square relative displacement of absorber and backscatter atoms, is known to increase with temperature. ${ }^{24}$ Consequently, the linear dependence of $\sigma^{2}$ with temperature was fitted using nonphase corrected Fourier transformed $\mathrm{Pd} K$-edge data collected of the calcined $\mathrm{PdO} / \gamma-\mathrm{Al}_{2} \mathrm{O}_{3}$ between 500 to $20{ }^{\circ} \mathrm{C}$, where all other parameters (delr and $S_{0}^{2}$ ) are assumed to be fixed. This variance in $\sigma^{2}$ with temperature, reported in Figure S1 of the Supporting Information, was used to fix $\sigma^{2}$ for the fitting of the EXAFS data collected during the calcination temperature ramp period.

Ex Situ Characterization. Thermogravimetric analysis was carried out in a TA thermogravimetric analyzer (instrument Q50/DSC Auto Q20) with a sample mass of $10 \mathrm{mg}$ placed in a platinum crucible under continuous flow of $40 \% \mathrm{~N}_{2}$ and $60 \%$ air and ramped at $10{ }^{\circ} \mathrm{C} \mathrm{min}{ }^{-1}$. Transmission electron microscopy (TEM) images of the samples were obtained using a JEOL JEM 2100 transmission electron microscope. Samples were prepared for TEM analysis by dispersing in high-purity ethanol using ultrasonication. Ten microliters of the sonicated suspension were pipetted onto a holey carbon supporting $\mathrm{Cu}$ grid, and the solvent evaporated. Ex situ Pd K-edge XAFS spectra of the calcined catalyst samples after reducing in $\mathrm{H}_{2}$ (at $100{ }^{\circ} \mathrm{C}$ ) were taken in transmission mode on $\mathrm{B} 18$ at Diamond Light Source. CO chemisorption of the calcined catalyst samples was performed with FTIR analysis in transmission mode. Samples $(20 \mathrm{mg})$ were pressed into self-supporting wafers $\left(1.35 \mathrm{~cm}^{2}\right)$, mounted in the transmission FTIR cell, and dried at $100{ }^{\circ} \mathrm{C}$ under constant flow of He. Several pulses of $\mathrm{CO}$ were introduced into the cell until saturation. The $\mathrm{CO}$ adsorption FTIR spectra were recorded $\left(40-4500 \mathrm{~cm}^{-1}, 4 \mathrm{~cm}^{-1}\right.$ resolution) after purging the cell with $\mathrm{He}(15 \mathrm{~min})$. Raman spectra were recorded using a Bruker Senterra microscope at B22, Diamond Light Source, using $532 \mathrm{~nm}$ laser at $5 \mathrm{~mW}$. XRD diffraction patterns were collected using a Rigaku Miniflex diffractometer (ISIS Materials Characterization $\mathrm{Lab}$ ) with a $600 \mathrm{~mW} \mathrm{Cu} \alpha$ tube source operated at 45 
$\mathrm{kV}$ and $15 \mathrm{~mA}$ and using a $1 \mathrm{D}$ Si strip detector. Sherrer calculations of the average crystallite sizes used the full width half-maximum of the diffraction peaks located at the $2 \theta$ angle $55^{\circ}$, assuming the Sherrer constant to be 0.94 . Catalytic light off curves for methane oxidation were obtained using JM automotive test rig, using a synthetic natural gas mixture $\left(0.5 \% \mathrm{CH}_{4}, 10 \% \mathrm{O}_{2}, 0.01 \% \mathrm{C}_{2} \mathrm{H}_{6}, 0.01 \% \mathrm{C}_{3} \mathrm{H}_{8}, 0.01 \%\right.$ NO, $10 \% \mathrm{CO}_{2}$, and $10 \% \mathrm{H}_{2} \mathrm{O}$ ), a gas hourly space velocity of 90000 $\mathrm{h}^{-1}$, and a temperature ramp rate of $15{ }^{\circ} \mathrm{C} \mathrm{min}^{-1}$. Effluent gases were analyzed by a MKS 2000 multigas FTIR analyzer.

\section{RESULTS AND DISCUSSION}

Ex Situ Characterization. Two 3 wt \% PdO catalysts supported on $\gamma-\mathrm{Al}_{2} \mathrm{O}_{3}$ were prepared by the impregnation and calcination from $\mathrm{Pd}\left(\mathrm{NO}_{3}\right)_{2}$ and $\mathrm{Pd}\left(\mathrm{NH}_{3}\right)_{4}(\mathrm{OH})_{2}$ to give catalysts $\mathrm{Pd} / \gamma-\mathrm{Al}_{2} \mathrm{O}_{3}$-ex $\left(\mathrm{NO}_{3}\right)$ and $\mathrm{Pd} / \gamma-\mathrm{Al}_{2} \mathrm{O}_{3}$-ex $\left(\mathrm{NH}_{3}\right)$, respectively. TEM images of the calcined catalysts (Figure 1)
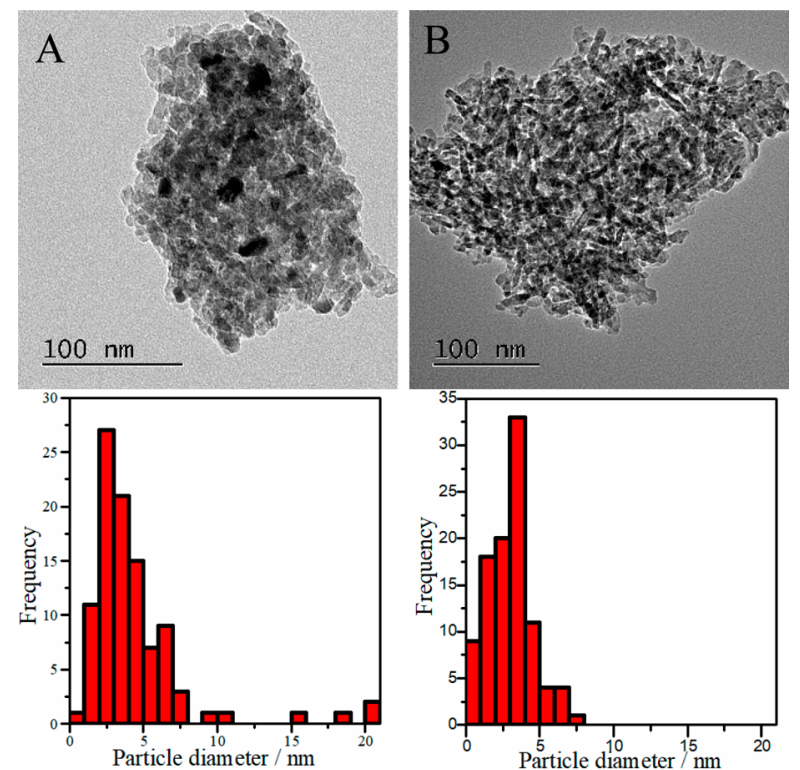

Figure 1. Particle size histogram and representative image of (A) $\mathrm{Pd} /$ $\gamma-\mathrm{Al}_{2} \mathrm{O}_{3}$-ex $\left(\mathrm{NO}_{3}\right)$ and (B) $\mathrm{Pd} / \gamma-\mathrm{Al}_{2} \mathrm{O}_{3}-\mathrm{ex}\left(\mathrm{NH}_{3}\right)$.

show dark Pd nanoparticles dispersed upon the contrasting lighter colored $\gamma-\mathrm{Al}_{2} \mathrm{O}_{3}$ support. Particle size analysis conducted over 100 measured particles revealed smaller average particle diameter $(3.1 \mathrm{~nm})$ for catalyst $\mathrm{Pd} / \gamma$ - $\mathrm{Al}_{2} \mathrm{O}_{3}$-ex $\left(\mathrm{NH}_{3}\right)$ compared to that of $\mathrm{Pd} / \gamma-\mathrm{Al}_{2} \mathrm{O}_{3}-\mathrm{ex}\left(\mathrm{NO}_{3}\right)(4.4 \mathrm{~nm})$. This is consistent with the presence of larger agglomerated particles $(>15 \mathrm{~nm})$ observed only for $\mathrm{Pd} / \gamma-\mathrm{Al}_{2} \mathrm{O}_{3}$-ex $\left(\mathrm{NO}_{3}\right)$, as shown clearly in the corresponding histogram of particle size distribution. Although only $5 \%$ of the 100 measured particles have a diameter greater than $15 \mathrm{~nm}$, this is significant when considering the mass fraction of Pd located at the core of larger particles rather than contributing to catalysis at the surface.

$\mathrm{X}$-ray diffraction patterns of both calcined catalyst samples show diffraction peaks assigned to cubic $\gamma-\mathrm{Al}_{2} \mathrm{O}_{3}$ (JPDS card no. 00-002-1420) similar to that of the fresh support, labeled with arrows in Figure 2, proving that structural integrity of the support is maintained after impregnation. Additional diffraction peaks located at $2 \theta$ angles of $42.6,55.6$, and $72,7^{\circ}$, labeled with asterisks in Figure 2, can be attributed to crystalline domains of tetragonal PdO (JCPDS card no. 00-002-1432). The full width half-maximum of these peaks indicates the relative crystallite size of the observed PdO particles pursuant to the Sherrer equation. ${ }^{25}$ Smaller intensity and increased broadening of PdO

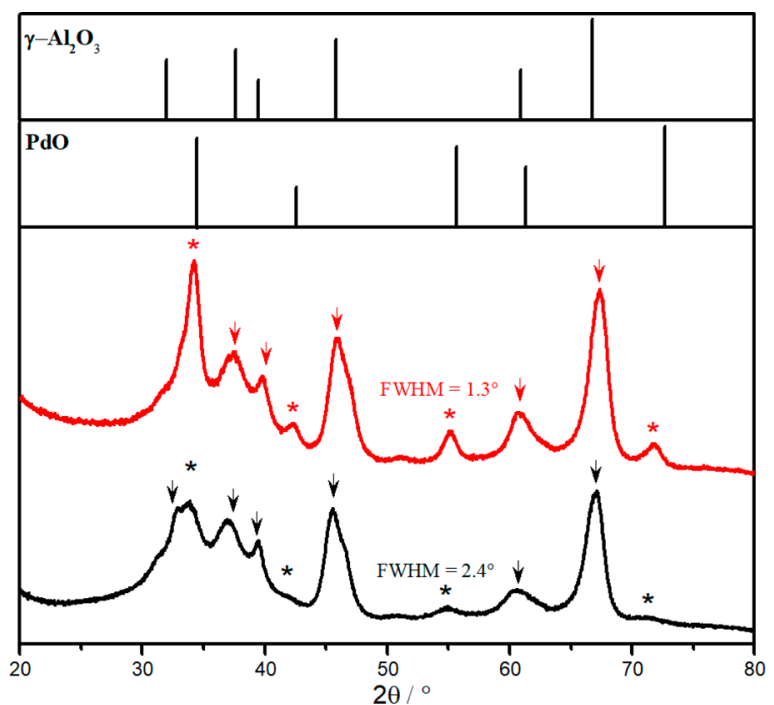

Figure 2. XRD patterns of calcined catalysts $\mathrm{Pd} / \gamma-\mathrm{Al}_{2} \mathrm{O}_{3}-\mathrm{ex}\left(\mathrm{NO}_{3}\right)$ and $\mathrm{Pd} / \gamma-\mathrm{Al}_{2} \mathrm{O}_{3}-\mathrm{ex}\left(\mathrm{NH}_{3}\right)$, shown in red and black, respectively. Top panels show the relative position and intensity of diffraction lines of $\gamma-\mathrm{Al}_{2} \mathrm{O}_{3}$ and $\mathrm{PdO}$ references.

diffraction peaks for $\mathrm{Pd} / \gamma-\mathrm{Al}_{2} \mathrm{O}_{3}$-ex $\left(\mathrm{NH}_{3}\right)$ suggests this sample has smaller PdO crystallite size of $6 \mathrm{~nm}$ compared to $11 \mathrm{~nm}$ for $\mathrm{Pd} / \gamma-\mathrm{Al}_{2} \mathrm{O}_{3}-\mathrm{ex}\left(\mathrm{NO}_{3}\right)$. Further evidence for the $\mathrm{PdO}$ structure is indicated by the Raman spectra of $\mathrm{Pd} / \gamma-\mathrm{Al}_{2} \mathrm{O}_{3}$-ex $\left(\mathrm{NO}_{3}\right)$ and $\mathrm{Pd} / \gamma-\mathrm{Al}_{2} \mathrm{O}_{3}-\mathrm{ex}\left(\mathrm{NH}_{3}\right)$ (Supporting Information, Figure S2), which show well-resolved bands positioned at 439 and 640 $\mathrm{cm}^{-1}$ associated with Raman active $\mathrm{E}_{\mathrm{g}}$ and $\mathrm{B}_{1 \mathrm{~g}}$ vibrational modes of $\mathrm{Pd}-\mathrm{O}$, respectively, in a $\mathrm{PdO}$ lattice. Difference in the respective peak area of the $B_{1 \mathrm{~g}}$ band (averaged from 6 spectra taken at different positions over each sample) indicates a greater number of $\mathrm{Pd}-\mathrm{O}$ vibrations from $\mathrm{Pd} / \gamma-\mathrm{Al}_{2} \mathrm{O}_{3}-\mathrm{ex}\left(\mathrm{NO}_{3}\right)$ compared to $\mathrm{Pd} / \gamma-\mathrm{Al}_{2} \mathrm{O}_{3}$-ex $\left(\mathrm{NH}_{3}\right)$, again indicating larger $\mathrm{PdO}$ crystallite size for $\mathrm{Pd} / \gamma-\mathrm{Al}_{2} \mathrm{O}_{3}$-ex $\left(\mathrm{NO}_{3}\right)^{26}$

Ex situ Pd K-edge XAFS spectra of the calcined catalyst samples were collected for compositional and quantitative information on the Pd environment in each case. The Pd $\mathrm{K}$ edge XANES show the Pd environment of each sample to be broadly consistent with $\mathrm{PdO}$ at room temperature (Supporting Information, Figure S3) with small differences in amplitude attributed to particle size effects. Under an $\mathrm{H}_{2}$ atmosphere, $\mathrm{PdO}$ nanoparticles of both samples were completely reduced to metallic Pd. A fitting model to the EXAFS data (Figure 3a) was achieved using the first shell scattering path, $\mathrm{Pd}-\mathrm{Pd}$, of metallic Pd with $\sigma^{2}$ value of $0.0065 \AA^{2}$. The amplitude of this fitted scattering feature gave $\mathrm{Pd}-\mathrm{Pd}$ coordination numbers of 10.3(4) for $\mathrm{Pd} / \gamma-\mathrm{Al}_{2} \mathrm{O}_{3}-\mathrm{ex}\left(\mathrm{NO}_{3}\right)$ and $7.5(2)$ for $\mathrm{Pd} / \gamma-\mathrm{Al}_{2} \mathrm{O}_{3}-\mathrm{ex}\left(\mathrm{NH}_{3}\right)$, corresponding to average particle diameters of 2.7(6) and 1.1(1) $\mathrm{nm}$, respectively, using a previously reported method detailed in the Supporting Information (Tables S1 and S2). ${ }^{27}$

$\mathrm{CO}$ can be used as a probe molecule in FTIR adsorption experiments to investigate surface adsorption properties of the catalyst materials. $^{28,29}$ Linear and bridge bonding of $\mathrm{CO}$ adsorbed on both $\mathrm{Pd} / \gamma-\mathrm{Al}_{2} \mathrm{O}_{3}$ samples were identified by the sharp band at $2071 \mathrm{~cm}^{-1}$ and the broad band between 1969 and $1830 \mathrm{~cm}^{-1}$, respectively (Figure $3 \mathrm{~b}$ )..$^{30-33}$ The significant difference in intensity of $\mathrm{CO}$ absorption bands from the two catalyst samples is consistent with $\mathrm{Pd} / \gamma-\mathrm{Al}_{2} \mathrm{O}_{3}-\mathrm{ex}\left(\mathrm{NH}_{3}\right)$ having larger surface area due to smaller particle size. Additionally, the type of surface sites can be clarified from the relative linear to 

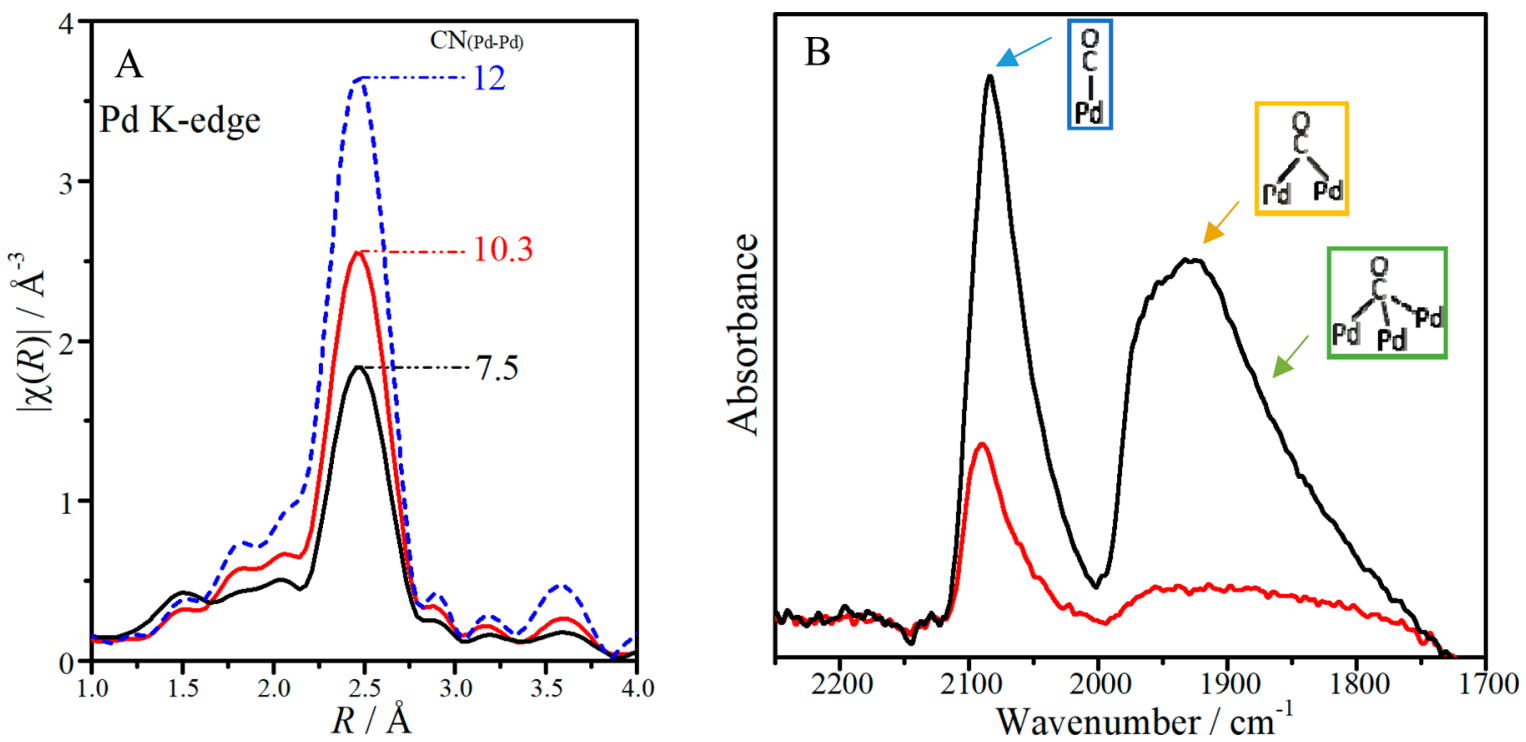

Figure 3. (A) Pd K-edge Fourier transform EXAFS data of calcined catalysts $\mathrm{Pd} / \gamma$ - $\mathrm{Al}_{2} \mathrm{O}_{3}$-ex $\left(\mathrm{NO}_{3}\right)$ (red) and $\mathrm{Pd} / \gamma$ - $\mathrm{Al}_{2} \mathrm{O}_{3}$-ex $\left(\mathrm{NH}_{3}\right)(\mathrm{black})$ reduced under $\mathrm{H}_{2}$ atmosphere and $\mathrm{Pd}$ foil (blue). (B) Transmission FTIR spectra of calcined catalysts $\mathrm{Pd} / \gamma-\mathrm{Al}_{2} \mathrm{O}_{3}$-ex $\left(\mathrm{NO}_{3}\right)(\mathrm{red})$ and $\mathrm{Pd} / \gamma$ - $\mathrm{Al}_{2} \mathrm{O}_{3}$-ex $\left(\mathrm{NH}_{3}\right)$ (black) after $\mathrm{CO}$ adsorption normalized to $20 \mathrm{mg}$ catalyst.

bridge bonding adsorption band intensity ratio, reported in Table 1. The greater ratio of linear to bridge bonded $\mathrm{CO}$ on

Table 1. Calcined $\mathrm{Pd} / \gamma-\mathrm{Al}_{2} \mathrm{O}_{3}$ Catalyst Characterization ${ }^{a}$

\begin{tabular}{|c|c|c|c|c|c|}
\hline & \multicolumn{2}{|c|}{$\begin{array}{l}\text { average particle } \\
\text { size }(\mathrm{nm})\end{array}$} & \multirow[b]{2}{*}{$\begin{array}{l}\text { PdO crystallite } \\
\text { size (XRD) } \\
(\mathrm{nm})\end{array}$} & \multirow[b]{2}{*}{$\begin{array}{l}\text { L/B ratio } \\
\text { (CO } \\
\text { FTIR) }\end{array}$} & \multirow[b]{2}{*}{$\begin{array}{r}T_{50} \\
\left({ }^{\circ} \mathrm{C}\right.\end{array}$} \\
\hline & TEM & EXAFS & & & \\
\hline $\begin{array}{l}\mathrm{Pd} / \gamma-\mathrm{Al}_{2} \mathrm{O}_{3}- \\
\quad \operatorname{ex}\left(\mathrm{NO}_{3}\right)^{-}\end{array}$ & 4.4 & $2.7(6)$ & 11 & 0.14 & 394 \\
\hline $\begin{array}{l}\mathrm{Pd} / \gamma-\mathrm{Al}_{2} \mathrm{O}_{3^{-}} \\
\quad \operatorname{ex}\left(\mathrm{NH}_{3}\right)_{4}(\mathrm{OH})_{2}\end{array}$ & 3.1 & $1.1(1)$ & 6 & 0.27 & 385 \\
\hline
\end{tabular}

${ }^{a}$ TEM average particle size, EXAFS average particle size, XRD PdO crystallite size, linear/bridged ratio (CO adsorption FTIR), and temperature required to achieve $50 \% \mathrm{CH}_{4}$ conversion during lean $\mathrm{CH}_{4}$ oxidation catalytic test $\left(\mathrm{T}_{50}\right)$.

$\mathrm{Pd} / \gamma-\mathrm{Al}_{2} \mathrm{O}_{3}-\mathrm{ex}\left(\mathrm{NH}_{3}\right)$ is indicative of a rough Pd surface with greater number of step and edge sites. ${ }^{32,34}$ The discrepancy between the average particle size calculated by the different methods, reported in Table 1 , is not surprising. The TEM is limited to the resolution and field of view of the microscope; $\mathrm{XRD}$ is limited to assess particles with sufficiently large crystalline domains, while EXAFS probes all Pd species in the sample. Despite these differences, there is consistent evidence for $\mathrm{Pd} / \gamma-\mathrm{Al}_{2} \mathrm{O}_{3}$-ex $\left(\mathrm{NH}_{3}\right)$ providing smaller average $\mathrm{PdO}$ crystallite size and greater dispersion over the support compared to $\mathrm{Pd} / \gamma-\mathrm{Al}_{2} \mathrm{O}_{3}$-ex $\left(\mathrm{NO}_{3}\right)$. Light off curves for $\mathrm{CH}_{4}$ conversion (Supporting Information, Figure S4) confirm that the catalyst with improved dispersion and smaller particle size, $\mathrm{Pd} / \gamma-\mathrm{Al}_{2} \mathrm{O}_{3}-\mathrm{ex}\left(\mathrm{NH}_{3}\right)$, is able to catalyze the complete oxidation of methane at a temperature that is lower than that of the catalyst possessing some larger agglomerated particles, $\mathrm{Pd} / \gamma$ $\mathrm{Al}_{2} \mathrm{O}_{3}$-ex $\left(\mathrm{NO}_{3}\right)$.

In Situ XAFS/DRIFTS of the Preparation Route. Pd Kedge EXAFS analysis of the impregnated precursor samples, $\mathrm{Pd}\left(\mathrm{NO}_{3}\right)_{2} / \gamma-\mathrm{Al}_{2} \mathrm{O}_{3}$ and $\mathrm{Pd}\left(\mathrm{NH}_{3}\right)_{4}(\mathrm{OH})_{2} / \gamma-\mathrm{Al}_{2} \mathrm{O}_{3}$ gave structural information on the initial $\mathrm{Pd}$ coordination environment after impregnation onto the $\gamma-\mathrm{Al}_{2} \mathrm{O}_{3}$ at room temperature. The $k^{2}$ weighted $\chi(k)$ EXAFS spectrum of the impregnate $\mathrm{Pd}\left(\mathrm{NH}_{3}\right)_{4}(\mathrm{OH})_{2} / \gamma-\mathrm{Al}_{2} \mathrm{O}_{3}$ compares closely to that of the unsupported aqueous $\mathrm{Pd}\left(\mathrm{NH}_{3}\right)_{4}(\mathrm{OH})_{2(\text { aq) }}$ solution (Figure $4 a)$. Conversely, the $k^{2}$ weighted $\chi(k)$ EXAFS spectra of the impregnated precursor $\mathrm{Pd}\left(\mathrm{NO}_{3}\right)_{2} / \gamma-\mathrm{Al}_{2} \mathrm{O}_{3}$ shows greater longrange structure from EXAFS oscillations extending to greater $k$ range $\left(\sim 10.4 \AA^{-1}\right)$ with additional scattering feature at $9 \AA^{-1}$ (annotated with an asterisk in Figure $4 \mathrm{~b}$ ) that is absent from the $\chi(k)$ EXAFS spectrum of the unsupported $\mathrm{Pd}$ $\left(\mathrm{NO}_{3}\right)_{2}\left(\mathrm{H}_{2} \mathrm{O}\right)_{x}$ reference. A simple fitting model was constructed from one calculated scattering path representative of four light atomic neighboring atoms ( $14 \leq$ atomic number, $Z$ $\leq 16$ ) located at $2.049 \AA$ from the absorbing Pd atom. This model was sufficient to fit the Fourier transformed EXAFS data of unsupported $\mathrm{Pd}\left(\mathrm{NH}_{3}\right)_{4}(\mathrm{OH})_{2(\mathrm{aq})}$ and impregnated Pd$\left(\mathrm{NH}_{3}\right)_{4}(\mathrm{OH})_{2} / \gamma-\mathrm{Al}_{2} \mathrm{O}_{3}$ (Figure $4 \mathrm{c}$ ), showing that the $\mathrm{Pd}^{2+}$ center in each case is coordinated to four oxygen or nitrogen atoms of ammonia, hydroxyl, or water ligands with little or no longer range structure, consistent with a $\left[\mathrm{Pd}\left(\mathrm{NH}_{3}\right)_{4}\right]^{2+}$ complex. This model was, however, inadequate to fit that of the impregnated $\mathrm{Pd}\left(\mathrm{NO}_{3}\right)_{2} / \gamma-\mathrm{Al}_{2} \mathrm{O}_{3}$. In this case, additional structure observed in the EXAFS data requires an additional scattering path to refine the EXAFS fitting model to this sample. A refined fit to $\mathrm{Pd}\left(\mathrm{NO}_{3}\right)_{2} / \gamma-\mathrm{Al}_{2} \mathrm{O}_{3}$, displayed as the red dashed line of Figure $4 \mathrm{~d}$, includes an additional scattering contribution from neighboring Pd atoms located $3.43 \AA$ from absorbing Pd. The distance is consistent with a $\mathrm{Pd}$ atom in a second coordination shell from the absorbing $\mathrm{Pd}$, which corresponds to neighboring $\mathrm{Pd}$ centers adjoined by bridging ligand coordination. It is noted that such a Pd distance (3.43 $\AA$ ) is close to that of the second coordination shell $\mathrm{Pd}$ atom in the crystal structure of tetrahedral PdO.

DRIFTS spectra of both precursor samples before calcination are reported in Figure 5a. The broad band centered at 3500 $\mathrm{cm}^{-1}$ can be assigned to symmetric and antisymmetric $\mathrm{O}-\mathrm{H}$ stretching vibrations of lattice water, and a sharp band at 1420 $\mathrm{cm}^{-1}$ is assigned to carbonate ions on the oxide support. ${ }^{35}$ Loss of these absorption bands indicate removal of $\mathrm{H}_{2} \mathrm{O}$ and $\mathrm{CO}_{3}{ }^{2-}$ upon heating to $200{ }^{\circ} \mathrm{C}$. The intensity of the FTIR absorption 

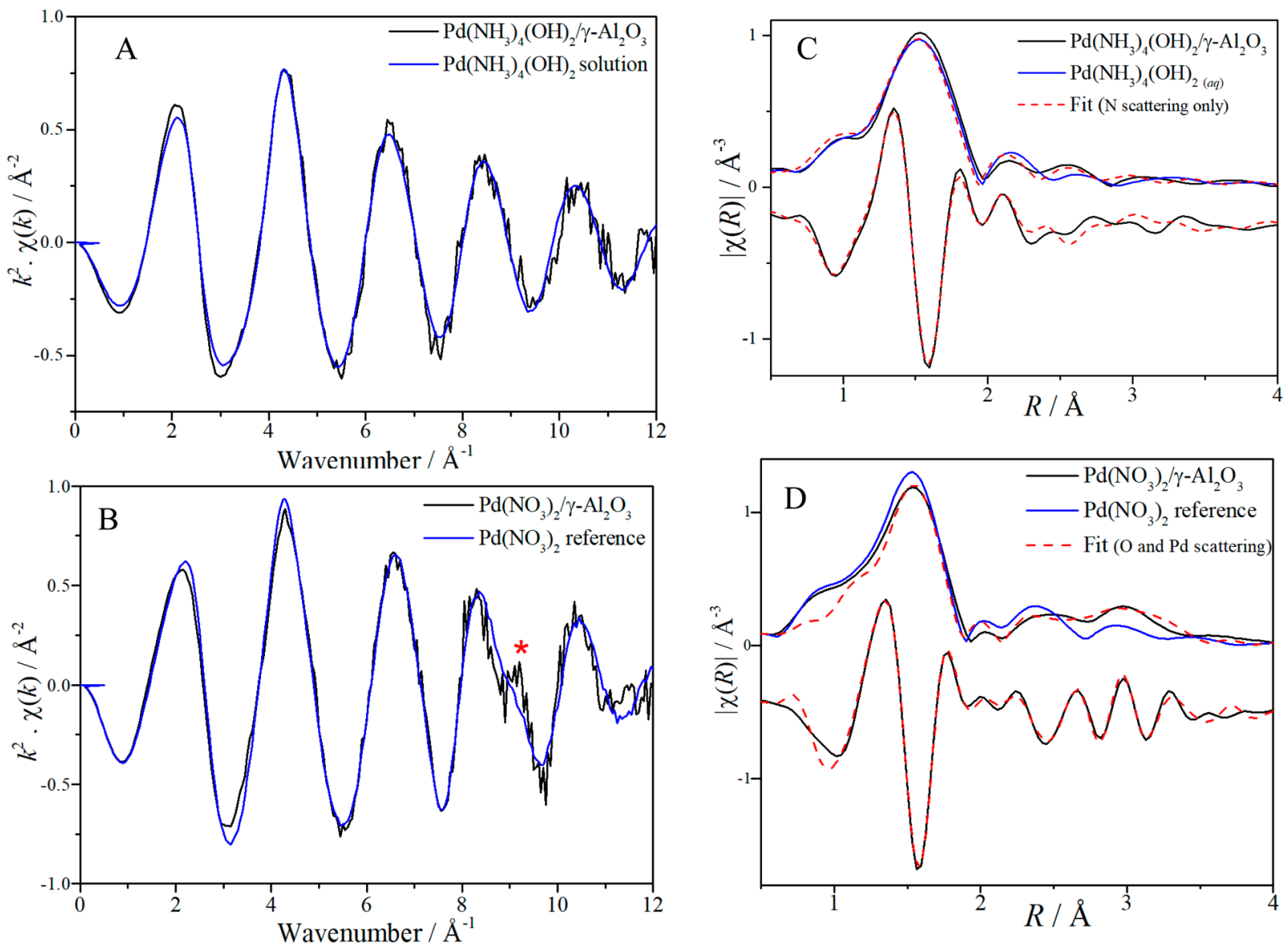

Figure 4. Pd K-edge $k^{2}$ weighted $\chi(k)$ EXAFS spectra and corresponding Fourier transform EXAFS data of $\mathrm{Pd}_{(}\left(\mathrm{NH}_{3}\right)_{4}(\mathrm{OH})_{2} / \gamma$ - $\mathrm{Al}_{2} \mathrm{O}_{3}($ top $)$ and $\mathrm{Pd}\left(\mathrm{NO}_{3}\right)_{2} / \gamma-\mathrm{Al}_{2} \mathrm{O}_{3}$ (bottom). Nonphase corrected Fourier transformed EXAFS data of precursor sample (black) plotted with corresponding unsupported reference $\mathrm{Pd}\left(\mathrm{NH}_{3}\right)_{4}(\mathrm{OH})_{2}$ (aq) and $\mathrm{Pd}\left(\mathrm{NO}_{3}\right)_{2}$ (blue) and the fitting model using first shell $\mathrm{Pd}_{(\mathrm{N}) 1}$ or $\mathrm{Pd}_{(\mathrm{O}) 2}$ and second shell $\mathrm{Pd}(\mathrm{Pd}) 2$ scattering paths (red, dashed).

bands in the spectral range 1250-1800 $\mathrm{cm}^{-1}$ during the calcination temperature ramp are shown as a color map in Figure $5 \mathrm{~b}$. The nitrate species of sample $\mathrm{Pd}\left(\mathrm{NO}_{3}\right)_{2} / \gamma-\mathrm{Al}_{2} \mathrm{O}_{3}$ can be identified by two molecular vibrational bands of $\mathrm{N}=\mathrm{O}$ stretching between 1650 and $1500 \mathrm{~cm}^{-1}$ and $\mathrm{O}-\mathrm{N}-\mathrm{O}$ asymmetrical stretching between 1350 and $1200 \mathrm{~cm}^{-1}, 36,37$ consistent with the calculated $\mathrm{N}=\mathrm{O}$ stretching frequency of bridging nitrates on an $\mathrm{Al}_{2} \mathrm{O}_{3}$ surface. ${ }^{38}$ Comparison with the DRIFTS spectra of the unsupported $\mathrm{Pd}\left(\mathrm{NO}_{3}\right)_{2}\left(\mathrm{H}_{2} \mathrm{O}\right)_{x}$ precursor and an acid treated $\gamma-\mathrm{Al}_{2} \mathrm{O}_{3} / \mathrm{HNO}_{3}$ (Supporting Information, Figure S5) shows the $\mathrm{O}-\mathrm{N}-\mathrm{O}$ asymmetrical stretching of nitrate coordinated to $\mathrm{Pd}^{2+}$ and $\gamma-\mathrm{Al}_{2} \mathrm{O}_{3}$ as absorption bands at 1320 and $1300 \mathrm{~cm}^{-1}$, respectively. The broad character of the $\mathrm{O}-\mathrm{N}-\mathrm{O}$ stretching band of $\mathrm{Pd}\left(\mathrm{NO}_{3}\right)_{2} /$ $\gamma-\mathrm{Al}_{2} \mathrm{O}_{3}$ can be seen to result from nitrate coordinated to both the $\mathrm{Pd}^{2+}$ cation and Lewis acid $\mathrm{Al}^{3+}$ sites of the $\gamma-\mathrm{Al}_{2} \mathrm{O}_{3}$. Beyond $100{ }^{\circ} \mathrm{C}$, the broad band initially centered at $1300 \mathrm{~cm}^{-1}$ begins to narrow and shift to lower frequency until it is centered at $1270 \mathrm{~cm}^{-1}$ by $200{ }^{\circ} \mathrm{C}$. The nitrate band previously centered at $1510 \mathrm{~cm}^{-1}$ also broadens and shifts over the same temperature range but toward higher wavenumbers until it is centered at $1570 \mathrm{~cm}^{-1}$ by $200{ }^{\circ} \mathrm{C}$ (annotated by arrows, Figure $5 \mathrm{~b}$ ). The shift in nitrate bands to greater separation is consistent with increased bidentate nitrate coordination to a metal center. ${ }^{38,39}$ The early preassociation of $\mathrm{Pd}$ species of $\mathrm{Pd}\left(\mathrm{NO}_{3}\right)_{2} / \gamma-\mathrm{Al}_{2} \mathrm{O}_{3}$, as indicated from EXAFS, can therefore also be supported by the
DRIFTS spectra which provide evidence for neighboring Pd centers to be linked by bridging nitrate coordination.

DRIFTS spectra of the precursor sample $\mathrm{Pd}\left(\mathrm{NH}_{3}\right)_{4}(\mathrm{OH})_{2}$ or $\mathrm{Pd}\left(\mathrm{NO}_{3}\right)_{2} / \gamma-\mathrm{Al}_{2} \mathrm{O}_{3}$ at room temperature show $\mathrm{H}-\mathrm{N}-\mathrm{H}$ vibrational modes of surface $\mathrm{NH}_{3}$ species as bands at 1490 and $1345 \mathrm{~cm}^{-1}$. Upon increasing temperature, the positions of the bands remain but also show steady decrease in intensity until complete removal by $225^{\circ} \mathrm{C}$. The detection of $\mathrm{N}_{2} \mathrm{O}$ in the effluent gas by online mass spectrometry up to this temperature (Supporting Information, Figure S6b) shows that the $\mathrm{NH}_{3}$ species are oxidized before leaving the chamber, consistent with previously reported catalytic activity for low temperature $\mathrm{NH}_{3}$ oxidation at Pd surface. Following the removal of $\mathrm{NH}_{3}$, weak intensity absorption bands for $\mathrm{N}=\mathrm{O}$ stretching vibrations of surface nitrosyl $\left(\mathrm{NO}^{-}{ }_{\text {ads }}\right)$ are revealed at 1510 and $1556 \mathrm{~cm}^{-1}$, respectively, highlighted by the red circle in Figure $5 \mathrm{c}$. The formation of $\mathrm{NO}^{-}$can be attributed to oxidative decomposition of $\mathrm{NH}_{3}$ ligands, which then form strong interaction with the $\gamma$ $\mathrm{Al}_{2} \mathrm{O}_{3}$ surface. The nitrosyl absorption bands are present in the DRIFTS spectra up to $400{ }^{\circ} \mathrm{C}$, which is consistent with previous temperature studies for stability of $\mathrm{NO}^{-}$adsorbed onto the $\gamma-\mathrm{Al}_{2} \mathrm{O}_{3}$ surface. ${ }^{40-42}$ The $\mathrm{M} / \mathrm{Z} 30$ signal detected by online mass spectrometry of the effluent gas from sample $\mathrm{Pd}\left(\mathrm{NH}_{3}\right)_{4}(\mathrm{OH})_{2} / \gamma-\mathrm{Al}_{2} \mathrm{O}_{3}$ between $390-450{ }^{\circ} \mathrm{C}$ (Supporting Information, Figure S6b) indicates a release of $\mathrm{NO}^{-}($ads $)$as $\mathrm{NO}$ gas at this temperature. Note that in the case of the $\mathrm{Pd}\left(\mathrm{NO}_{3}\right)_{2} /$ $\gamma-\mathrm{Al}_{2} \mathrm{O}_{3}$ sample, the formation of $\mathrm{NO}^{-}$species is unlikely as the 


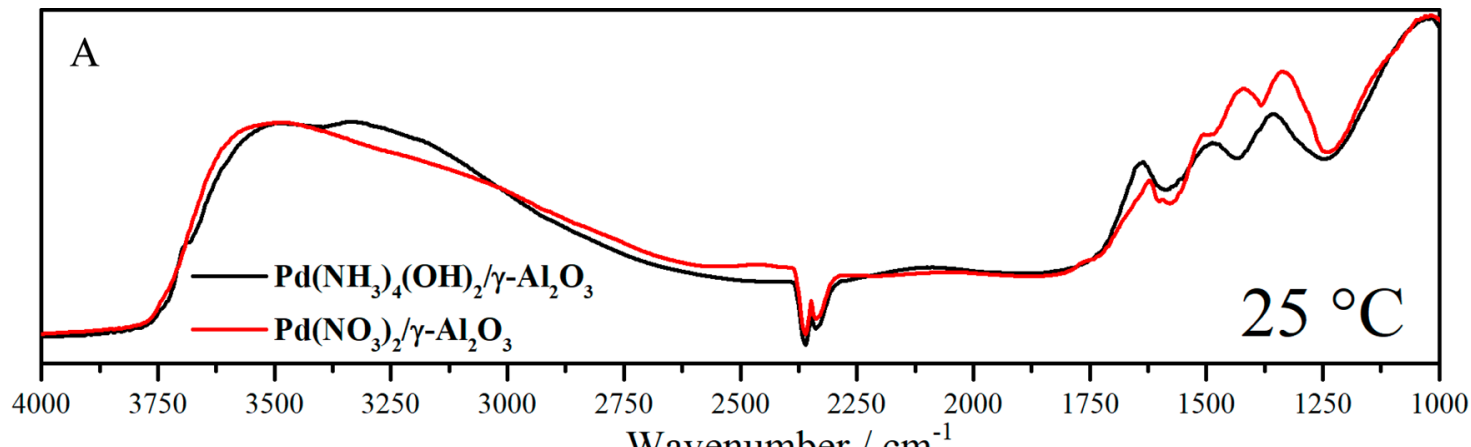

Wavenumber $/ \mathrm{cm}^{-1}$
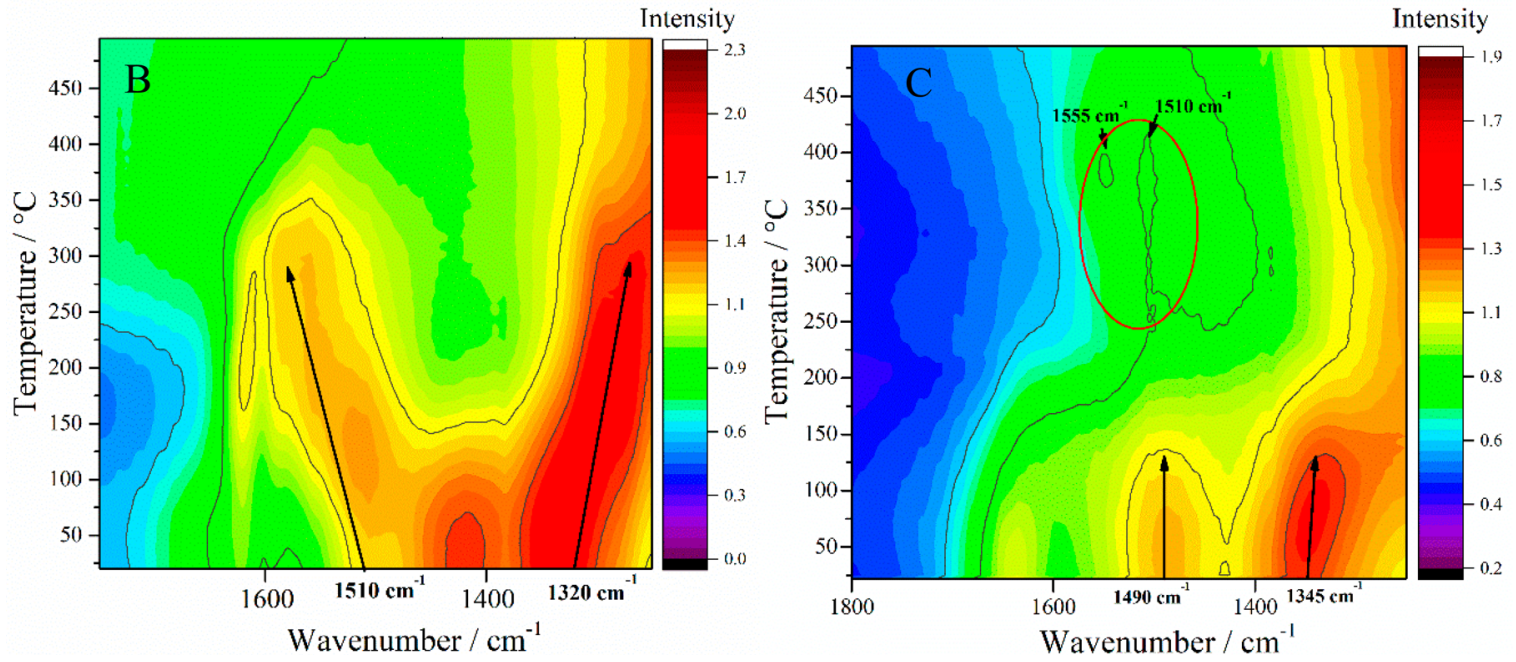

Figure 5. DRIFTS spectra of $\mathrm{Pd}\left(\mathrm{NO}_{3}\right)_{2} / \gamma-\mathrm{Al}_{2} \mathrm{O}_{3}$ (red) and $\mathrm{Pd}\left(\mathrm{NH}_{3}\right)_{4}(\mathrm{OH})_{2} / \gamma-\mathrm{Al}_{2} \mathrm{O}_{3}$ (black) at room temperature before calcination (A, top). Color maps of absorption intensities of time-resolved DRIFTS spectra at increasing temperature during calcination ramping period showing nitrate absorption bands of $\mathrm{Pd}\left(\mathrm{NO}_{3}\right)_{2} / \gamma-\mathrm{Al}_{2} \mathrm{O}_{3}\left(\mathrm{~B}\right.$, bottom left) and $\mathrm{Pd}\left(\mathrm{NH}_{3}\right)_{4}(\mathrm{OH})_{2} / \gamma-\mathrm{Al}_{2} \mathrm{O}_{3}(\mathrm{C}$, bottom right).
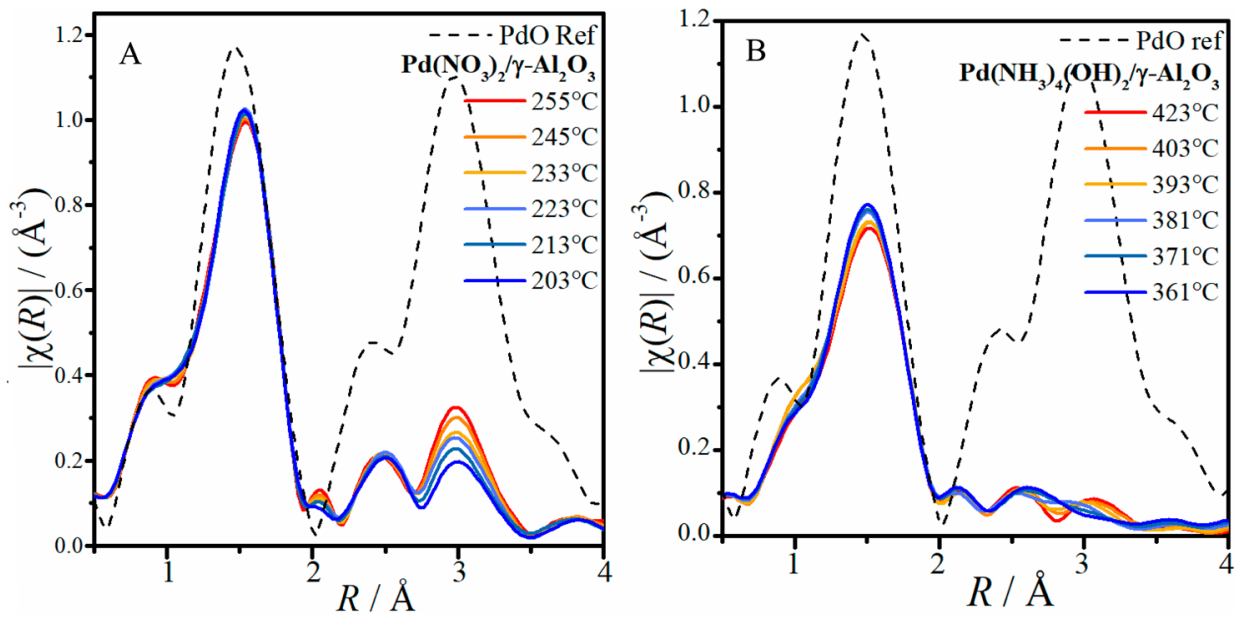

Figure 6. Nonphase corrected Fourier transformed EXAFS plots of (A) $\mathrm{Pd}\left(\mathrm{NO}_{3}\right)_{2} / \gamma-\mathrm{Al}_{2} \mathrm{O}_{3}$ and (B) $\mathrm{Pd}\left(\mathrm{NH}_{3}\right)_{4}(\mathrm{OH})_{2} / \gamma-\mathrm{Al}_{2} \mathrm{O}_{3}$ at increasing temperatures during the calcination ramp and reference $\mathrm{PdO}$ sample (dashed) at room temperature.

nitrogen of the nitrate ligands is already in higher oxidation state and thus is released in the oxidizing environment directly as $\mathrm{NO}$ gas $\left(\right.$ or $\mathrm{NO}_{2}$ ), which is detected as $\mathrm{M} / \mathrm{Z} 30$ between 100 and $400{ }^{\circ} \mathrm{C}$ (Supporting Information, Figure S6a).

The nucleation and growth of $\mathrm{PdO}$ nanoparticles from each impregnated precursor can be followed from the amplitude of the scattering features of the Fourier transform Pd K-edge EXAFS data collected during the calcination ramp period, shown in Figure 6. The scattering features at 2.5 and $3 \AA$ correspond to scattering from nearest neighbor $\mathrm{Pd}$ atoms (located at real distances of 3.05 and $3.43 \AA$ ) in the tetrahedral $\mathrm{PdO}$ crystal structure. ${ }^{43,44}$ An increase in amplitude of these features at higher temperatures, despite increasing thermal motion and thus increased dampening from thermal disorder, indicates an increase in coordination to neighboring $\mathrm{Pd}$ atoms and thus growth of the $\mathrm{PdO}$ structure. For $\mathrm{Pd}\left(\mathrm{NO}_{3}\right)_{2} / \gamma-\mathrm{Al}_{2} \mathrm{O}_{3}$, the scattering feature at $3 \AA$ in the Fourier transform EXAFS data is first observed at room temperature (Figure $4 d$ ) and 
starts to increase in amplitude when the sample is heated beyond $200{ }^{\circ} \mathrm{C}$ (Figure 6a). This shows that the distances between neighboring $\mathrm{Pd}$ atoms of the impregnated sample before calcination, thought to be associated via bridging nitrate coordination, do not change significantly upon adopting the $\mathrm{Pd}-\mathrm{O}-\mathrm{Pd}$ arrangement of tetrahedral PdO. For precursor sample $\mathrm{Pd}\left(\mathrm{NH}_{3}\right)_{4}(\mathrm{OH})_{2} / \gamma-\mathrm{Al}_{2} \mathrm{O}_{3}$, the amplitude of scattering features in this low temperature period $\left(200-360{ }^{\circ} \mathrm{C}\right)$ decreases with temperature due to the dampening effect of increasing EXAFS Debye-Waller factor $\left(\sigma^{2}\right)$ with increasing thermal disorder. This is a clear indication that there is no increase in local coordination around the absorbing Pd atoms during this low temperature period. Introduction of the second shell Pd-Pd distance (3.43 $\AA$ ) appears beyond $360{ }^{\circ} \mathrm{C}$. This is shown in Figure $6 \mathrm{~b}$ by the formation and growth in amplitude of the scattering feature at $3 \AA$. The coordination number of neighboring palladium atoms located at $3.43 \AA$ from the absorbing palladium is plotted against temperature for both samples (Supporting Information, Figure S7). The analysis shows that nucleation of $\mathrm{PdO}$ nanoparticles from the $\mathrm{Pd}\left(\mathrm{NH}_{3}\right)_{4}(\mathrm{OH})_{2}$ precursor occurs later in the calcination step than for the $\mathrm{Pd}\left(\mathrm{NO}_{3}\right)_{2}$ precursor, and growth occurs to a lesser extent. The $\mathrm{PdO}$ nanoparticle formation from ion exchanged molecular precursors $\mathrm{Pd}\left(\mathrm{NO}_{3}\right)_{2} / \gamma-\mathrm{Al}_{2} \mathrm{O}_{3}$ and $\mathrm{Pd}$ $\left(\mathrm{NH}_{3}\right)_{4}(\mathrm{OH})_{2} / \gamma-\mathrm{Al}_{2} \mathrm{O}_{3}$ has been found to occur at differing temperatures of the calcination ramping period. $\mathrm{Pd}\left(\mathrm{NO}_{3}\right)_{2} / \gamma$ $\mathrm{Al}_{2} \mathrm{O}_{3}$ showed significant intermolecular interaction before heat treatment, whereas $\mathrm{Pd}\left(\mathrm{NH}_{3}\right)_{4}(\mathrm{OH})_{2} / \gamma-\mathrm{Al}_{2} \mathrm{O}_{3}$ showed isolation of $\mathrm{Pd}$ centers. This would be expected due to strong initial interactions of $\left[\mathrm{Pd}\left(\mathrm{NH}_{3}\right)_{4}\right]^{2+}$ cations with the negatively charged $\mathrm{Al}-\mathrm{O}^{-}$surface sites (as alumina is deprotonated by $\mathrm{OH}^{-}$ions during incipient wetness impregnation) and is similarly observed for ion exchange of $\mathrm{Pt}\left(\mathrm{NH}_{3}\right)_{4}(\mathrm{OH})_{2}$ onto $\mathrm{SiO}_{2}$ surface. ${ }^{45}$ It is worth noting that the temperature for $\mathrm{NO}^{-}$ desorption from this sample, evidenced by loss of $\mathrm{N}=\mathrm{O}$ stretching bands in DRIFTS spectra and presence of $\mathrm{NO}_{(\mathrm{g})}$ in effluent gas between $360-400{ }^{\circ} \mathrm{C}$, correlates with the temperature at which $\mathrm{Pd}-\mathrm{Pd}$ scattering paths were first identified from the EXAFS data. The stabilizing effect of NO species has been previously postulated in multiple studies by Sietsma et al., whereby introducing NO gas into the calcination atmosphere was shown to suppress nanoparticle agglomeration over metal oxide support. ${ }^{46,47}$ It is possible that a combination of both high initial Pd dispersion and $\mathrm{NO}^{-}($ads) stabilization contributed to the later formation and suppressed growth of $\mathrm{PdO}$ nanoparticles from the $\mathrm{Pd}\left(\mathrm{NH}_{3}\right)_{4}(\mathrm{OH})_{2}$ precursor.

\section{CONCLUSIONS}

Through use of a combined XAFS/DRIFTS approach to study the formation of supported nanoparticles during calcination of impregnated metal oxides, a molecular insight into the role of different inorganic precursors was achieved. $\mathrm{Pd} / \gamma-\mathrm{Al}_{2} \mathrm{O}_{3}$ prepared from incipient wetness impregnation of aqueous $\mathrm{Pd}\left(\mathrm{NH}_{3}\right)_{4}(\mathrm{OH})_{2}$ solution benefits from smaller Pd particle size and improved dispersion over the support, which in turn favors a lower light off temperature for $\mathrm{CH}_{4}$ oxidation compared to that of the catalyst prepared from $\mathrm{Pd}\left(\mathrm{NO}_{3}\right)_{2}$.

The nucleation and growth of PdO nanoparticles during calcination was identified from the EXAFS data by an increase in the Pd-Pd scattering contribution located at a distance (3.43 $\AA$ ) consistent with a $\mathrm{Pd}-\mathrm{Pd}$ distance of crystalline PdO. For $\mathrm{Pd}\left(\mathrm{NO}_{3}\right)_{2} / \gamma-\mathrm{Al}_{2} \mathrm{O}_{3}$, early association of $\mathrm{Pd}$ neighbors at this distance $(3.43 \AA)$ was observed in the EXAFS data of the sample before heat treatment; the bridging nature of nitrate ligands in this sample, evidenced by $\mathrm{N}=\mathrm{O}$ and $\mathrm{O}-\mathrm{N}-\mathrm{O}$ nitrate stretching frequencies in DRIFTS spectra, provides a rationale for the early assembly of $\mathrm{Pd}$ centers via bridging mechanism. Upon calcination of the $\mathrm{Pd}\left(\mathrm{NO}_{3}\right)_{2} / \gamma-\mathrm{Al}_{2} \mathrm{O}_{3}$ sample, there was a pronounced increase in the $\mathrm{Pd}-\mathrm{Pd}$ scattering component at $3.43 \AA$ between $200-250{ }^{\circ} \mathrm{C}$, indicative of significant growth of $\mathrm{PdO}$ nanoparticles at this temperature. Conversely, the $\mathrm{Pd}$ centers from precursor $\mathrm{Pd}\left(\mathrm{NH}_{3}\right)_{4}(\mathrm{OH})_{2} / \gamma-\mathrm{Al}_{2} \mathrm{O}_{3}$ appear to adopt isolated sites upon impregnation, evidenced by the absence of any $\mathrm{Pd}-\mathrm{Pd}$ distances from the Pd EXAFS data, which can be explained by fast ion exchange of $\left[\mathrm{Pd}\left(\mathrm{NH}_{3}\right)_{4}\right]^{2+}$ with deprotonated $\mathrm{Al}-$ $\mathrm{O}^{-}$surface sites of the support. Although $\mathrm{NH}_{3}$ ligands were shown to decompose from the impregnated sample below 200 ${ }^{\circ} \mathrm{C}$, the formation of $\mathrm{PdO}$ nanoparticles (observed by $\mathrm{Pd}-\mathrm{Pd}$ scattering from EXAFS data) did not occur until temperatures beyond $360{ }^{\circ} \mathrm{C}$. Most $\mathrm{NH}_{3}$ was partially oxidized and released as $\mathrm{N}_{2} \mathrm{O}$ gas at $210{ }^{\circ} \mathrm{C}$, but small amounts of $\mathrm{NO}^{-}$were captured by the $\gamma-\mathrm{Al}_{2} \mathrm{O}_{3}$ surface, evidenced by $\mathrm{N}=\mathrm{O}$ stretching vibrations (1510 and $1556 \mathrm{~cm}^{-1}$ ) in DRIFTS spectra and evolution of $M / Z 30$ in online mass spectrometry of the effluent gas upon their removal. Strong ionic interaction of $\left[\mathrm{Pd}\left(\mathrm{NH}_{3}\right)_{2}\right]^{2+}$ with the support and the possible role of adsorbed $\mathrm{NO}^{-}$result in stabilization of isolated $\mathrm{PdO}$ species on $\gamma-\mathrm{Al}_{2} \mathrm{O}_{3}$ for the preparation of a highly dispersed $\mathrm{Pd} / \gamma-\mathrm{Al}_{2} \mathrm{O}_{3}$ catalyst material.

\section{ASSOCIATED CONTENT}

\section{Supporting Information}

The Supporting Information is available free of charge on the ACS Publications website at DOI: 10.1021/acs.chemmater.7b02552.

EXAFS fitting parameters, Raman emission spectra, XANES spectra, EXAFS particle size calculations, catalytic light off curves, reference DRIFTS spectra, TGA curves, and mass spectrometry data (PDF)

\section{AUTHOR INFORMATION}

\section{Corresponding Authors}

*E-mail: p.p.wells@soton.ac.uk.

*E-mail: a.goguet@qub.ac.uk.

ORCID $\odot$

Christopher Hardacre: 0000-0001-7256-6765

Peter P. Wells: 0000-0002-0859-9172

Funding

UK Catalysis Hub Consortium and EPSRC (Grants EP/ K014706/1, EP/K014668/1, EP/K014854/1, EP/K014714/1, and EP/I019693/1).

\section{Notes}

The authors declare no competing financial interest.

All data supporting this study are openly available from the University of Southampton repository at https://doi.org/10. 5258/SOTON/D0203.

\section{ACKNOWLEDGMENTS}

The authors acknowledge Diamond Light Source and beamline staff for provision of beam time (Experiment sp10306). The $\mathrm{RCaH}$ are acknowledged for use of facilities and staff support. Gavin Stenning at ISIS Materials Characterisation Lab is acknowledged for training and use of their instrumentation in 
this study. Mark Frogley at B22, Diamond Light Source is thanked for assistance with operating the Raman microscope. Johnson Matthey is acknowledged for their provision of precursor materials and catalyst testing facility. The UK Catalysis Hub is kindly thanked for resources and support provided via our membership of the UK Catalysis Hub Consortium. UCL and EPSRC are thanked for the iCASE studentship of E.K.D.

\section{ABBREVIATIONS}

DRIFTS, diffuse reflectance infrared Fourier transform spectroscopy

EXAFS, extended X-ray absorption fine structure

XANES, X-ray absorption near-edge structure

TEM, transmission electron microscopy

FTIR, Fourier transformed infrared

XAFS, X-ray absorption fine structure

$\mathrm{XRD}, \mathrm{X}$-ray diffraction

\section{REFERENCES}

(1) Hassani Rad, S. J.; Haghighi, M.; Alizadeh Eslami, A.; Rahmani, F.; Rahemi, N. Sol-gel vs. impregnation preparation of $\mathrm{MgO}$ and $\mathrm{CeO} 2$ doped $\mathrm{Ni} / \mathrm{Al} 2 \mathrm{O} 3$ nanocatalysts used in dry reforming of methane: Effect of process conditions, synthesis method and support composition. Int. J. Hydrogen Energy 2016, 41 (11), 5335-5350.

(2) Baeza, J. A.; Calvo, L.; Rodriguez, J. J.; Gilarranz, M. A. Catalysts based on large size-controlled Pd nanoparticles for aqueous-phase hydrodechlorination. Chem. Eng. J. 2016, 294, 40-48.

(3) Xiao, L.-h.; Sun, K.-p.; Xu, X.-1.; Li, X.-n. Low-temperature catalytic combustion of methane over $\mathrm{Pd} / \mathrm{CeO} 2$ prepared by deposition-precipitation method. Catal. Commun. 2005, 6 (12), 796-801.

(4) Persson, K.; Thevenin, P. O.; Jansson, K.; Agrell, J.; Järås, S. G.; Pettersson, L. J. Preparation of alumina-supported palladium catalysts for complete oxidation of methane. Appl. Catal., A 2003, 249 (1), 165-174.

(5) Ojala, S.; Bion, N.; Baylet, A.; Tarighi, M.; Keiski, R. L.; Duprez, D. Correlations between oxygen activation and methane oxidation over $\mathrm{Pd} / \gamma$-Al2O 3 catalysts prepared by nitrite method. Appl. Catal., B 2011, 108-109, 22-31.

(6) Panpranot, J.; Kaewkun, S.; Praserthdam, P.; Goodwin, J. G. Effect of Cobalt Precursors on the Dispersion of Cobalt on MCM-41. Catal. Lett. 2003, 91 (1), 95-102.

(7) Miller, J. T.; Schreier, M.; Kropf, A. J.; Regalbuto, J. R. A fundamental study of platinum tetraammine impregnation of silica: 2 . The effect of method of preparation, loading, and calcination temperature on (reduced) particle size. J. Catal. 2004, 225 (1), 203-212.

(8) Brunelle, J. P. Pure Appl. Chem. 1978, 50 (9-10), 1211-1229.

(9) Mahata, N.; Vishwanathan, V. Influence of Palladium Precursors on Structural Properties and Phenol Hydrogenation Characteristics of Supported Palladium Catalysts. J. Catal. 2000, 196 (2), 262-270.

(10) Moronta, A.; Troconis, M. E.; González, E.; Morán, C.; Sánchez, J.; González, A.; Quiñónez, J. Dehydrogenation of ethylbenzene to styrene catalyzed by $\mathrm{Co}$, Mo and CoMo catalysts supported on natural and aluminum-pillared clays: Effect of the metal reduction. Appl. Catal., A 2006, 310, 199-204.

(11) Gopinath, R.; Lingaiah, N.; Seshu Babu, N.; Suryanarayana, I.; Sai Prasad, P. S.; Obuchi, A. A highly active low Pd content catalyst synthesized by deposition-precipitation method for hydrodechlorination of chlorobenzene. J. Mol. Catal. A: Chem. 2004, 223 (1-2), 289293.

(12) Benkhaled, M.; Morin, S.; Pichon, C.; Thomazeau, C.; Verdon, C.; Uzio, D. Synthesis of highly dispersed palladium alumina supported particles: Influence of the particle surface density on physico-chemical properties. Appl. Catal., A 2006, 312, 1-11.
(13) Zou, W.; Gonzalez, R. D. The preparation of silica supported Pd catalysts: the effect of pretreatment variables on particle size. Catal. Lett. 1992, 12 (1), 73-86.

(14) Lashina, E. A.; Slavinskaya, E. M.; Chumakova, N. A.; Stonkus, O. A.; Gulyaev, R. V.; Stadnichenko, A. I.; Chumakov, G. A.; Boronin, A. I.; Demidenko, G. V. Self-sustained oscillations in CO oxidation reaction on $\mathrm{PdO} / \mathrm{Al}_{2} \mathrm{O}_{3}$ catalyst. Chem. Eng. Sci. 2012, 83, 149-158.

(15) Choudhary, V. R; Jana, P. Direct oxidation of $\mathrm{H} 2$ to $\mathrm{H} 2 \mathrm{O} 2$ over $\mathrm{PdO} / \mathrm{Al}_{2} \mathrm{O}_{3}$ catalysts in aqueous acidic medium: Influence on $\mathrm{H}_{2} \mathrm{O}_{2}$ formation of Pd loading, calcination temperature and reduction of catalyst and presence of halide anions. Catal. Commun. 2008, 9 (14), $2371-2375$.

(16) Majhi, A.; Sharma, Y. K.; Bal, R.; Behera, B.; Kumar, J. Upgrading of bio-oils over $\mathrm{PdO} / \mathrm{Al}_{2} \mathrm{O}_{3}$ catalyst and fractionation. Fuel 2013, 107, 131-137.

(17) Chen, X.; Cheng, Y.; Seo, C. Y.; Schwank, J. W.; McCabe, R. W. Aging, re-dispersion, and catalytic oxidation characteristics of model $\mathrm{Pd} / \mathrm{Al}_{2} \mathrm{O}_{3}$ automotive three-way catalysts. Appl. Catal., B 2015, 163, 499-509.

(18) Baldwin, T. R.; Burch, R. Remarkable activity enhancement in the catalytic combustion of methane on supported palladium catalysts. Catal. Lett. 1990, 6 (1), 131-138.

(19) Gélin, P.; Primet, M. Complete oxidation of methane at low temperature over noble metal based catalysts: a review. Appl. Catal., B 2002, 39 (1), 1-37.

(20) Yoshida, H.; Nakajima, T.; Yazawa, Y.; Hattori, T. Support effect on methane combustion over palladium catalysts. Appl. Catal., B 2007, 71 (1-2), 70-79.

(21) Hayes, R. E.; Kolaczkowski, S. T.; Li, P. K. C.; Awdry, S. The palladium catalysed oxidation of methane: reaction kinetics and the effect of diffusion barriers. Chem. Eng. Sci. 2001, 56 (16), 4815-4835.

(22) Espinosa-Alonso, L.; Beale, A. M.; Weckhuysen, B. M. Profiling physicochemical changes within catalyst bodies during preparation: New insights from invasive and noninvasive microspectroscopic studies. Acc. Chem. Res. 2010, 43 (9), 1279-1288.

(23) Gibson, E. K.; Beale, A. M.; Catlow, C. R. A.; Chutia, A.; Gianolio, D.; Gould, A.; Kroner, A.; Mohammed, K. M. H.; Perdjon, M.; Rogers, S. M.; Wells, P. P. Restructuring of AuPd Nanoparticles Studied by a Combined XAFS/DRIFTS Approach. Chem. Mater. 2015, 27 (10), 3714-3720.

(24) Bohmer, W.; Rabe, P. Temperature dependence of the mean square relative displacements of nearest-neighbour atoms derived from EXAFS spectra. J. Phys. C: Solid State Phys. 1979, 12 (13), 2465.

(25) Langford, J. I.; Wilson, A. J. C. Scherrer after sixty years: A survey and some new results in the determination of crystallite size. J. Appl. Crystallogr. 1978, 11 (2), 102-113.

(26) Otto, K.; Hubbard, C. P.; Weber, W. H.; Graham, G. W. Raman spectroscopy of palladium oxide on $\gamma$-alumina applicable to automotive catalysts: Nondestructive, quantitative analysis; oxidation kinetics; fluorescence quenching. Appl. Catal., B 1992, 1 (4), 317-327.

(27) Beale, A. M.; Weckhuysen, B. M. EXAFS as a tool to interrogate the size and shape of mono and bimetallic catalyst nanoparticles. Phys. Chem. Chem. Phys. 2010, 12 (21), 5562-5574.

(28) Spielbauer, D.; Mekhemer, G. A. H.; Zaki, M. I.; Knözinger, H. Acidity of sulfated zirconia as studied by FTIR spectroscopy of adsorbed $\mathrm{CO}$ and $\mathrm{NH}_{3}$ as probe molecules. Catal. Lett. 1996, 40 (1), $71-79$.

(29) Mihaylov, M.; Hadjiivanov, K. FTIR Study of CO and NO Adsorption and Coadsorption on Ni-ZSM-5 and Ni/SiO2. Langmuir 2002, 18 (11), 4376-4383.

(30) Tessier, D.; Rakai, A.; Bozon-Verduraz, F. Spectroscopic study of the interaction of carbon monoxide with cationic and metallic palladium in palladium-alumina catalysts. J. Chem. Soc., Faraday Trans. 1992, 88 (5), 741-749.

(31) Eischens, R. P.; Francis, S. A.; Pliskin, W. A. The Effect of Surface Coverage on the Spectra of Chemisorbed CO. J. Phys. Chem. 1956, 60 (2), 194-201. 
(32) Cabilla, G. C.; Bonivardi, A. L.; Baltanás, M. A. Characterization by CO/FTIR spectroscopy of $\mathrm{Pd} /$ silica catalysts and its correlation with syn-gas conversion. Catal. Lett. 1998, 55 (3), 147-156.

(33) Haneda, M.; Todo, M.; Nakamura, Y.; Hattori, M. Effect of Pd dispersion on the catalytic activity of $\mathrm{Pd} / \mathrm{Al}_{2} \mathrm{O}_{3}$ for $\mathrm{C}_{3} \mathrm{H}_{6}$ and $\mathrm{CO}$ oxidation. Catal. Today 2017, 281 (Part 3), 447-453.

(34) Hicks, R. F.; Bell, A. T. Effects of metal-support interactions on the hydrogenation of $\mathrm{CO}$ over $\mathrm{PdSiO}_{2}$ and $\mathrm{PdLa}_{2} \mathrm{O}_{3}$. J. Catal. 1984, 90 (2), 205-220.

(35) Schmal, M.; Souza, M. M. V. M; Alegre, V. V.; Silva, M. A. p.; César, D. V.; Perez, C. A. C. Catal. Today 2006, 118, 392-401.

(36) Meunier, F. C.; Breen, J. P.; Zuzaniuk, V.; Olsson, M.; Ross, J. R. $\mathrm{H}$. Mechanistic Aspects of the Selective Reduction of NO by Propene over Alumina and Silver-Alumina Catalysts. J. Catal. 1999, 187 (2), 493-505.

(37) Wichterlová, B.; Sazama, P.; Breen, J. P.; Burch, R.; Hill, C. J.; Čapek, L.; Sobalík, Z. An in situ UV-vis and FTIR spectroscopy study of the effect of $\mathrm{H}_{2}$ and $\mathrm{CO}$ during the selective catalytic reduction of nitrogen oxides over a silver alumina catalyst. J. Catal. 2005, 235 (1), 195-200.

(38) Zhang, X.; He, H.; Gao, H.; Yu, Y. Experimental and theoretical studies of surface nitrate species on $\mathrm{Ag} / \mathrm{Al}_{2} \mathrm{O}_{3}$ using DRIFTS and DFT. Spectrochim. Acta, Part A 2008, 71 (4), 1446-1451.

(39) Gatehouse, B. M.; Livingstone, S. E.; Nyholm, R. S. Infrared spectra of some nitrato and other oxy-anion co-ordination complexes. J. Inorg. Nucl. Chem. 1958, 8, 75-78.

(40) Westerberg, B.; Fridell, E. A transient FTIR study of species formed during $\mathrm{NO}_{\mathrm{x}}$ storage in the $\mathrm{Pt} / \mathrm{BaO} / \mathrm{Al}_{2} \mathrm{O}_{3}$ system. J. Mol. Catal. A: Chem. 2001, 165 (1-2), 249-263.

(41) Tamm, S.; Vallim, N.; Skoglundh, M.; Olsson, L. The influence of hydrogen on the stability of nitrates during $\mathrm{H}_{2}$-assisted SCR over $\mathrm{Ag} / \mathrm{Al}_{2} \mathrm{O}_{3}$ catalysts - A DRIFT study. J. Catal. 2013, 307, 153-161.

(42) Kameoka, S.; Ukisu, Y.; Miyadera, T. Selective catalytic reduction of $\mathrm{NO}_{\mathrm{x}}$ with $\mathrm{CH}_{3} \mathrm{OH}, \mathrm{C}_{2} \mathrm{H}_{5} \mathrm{OH}$ and $\mathrm{C}_{3} \mathrm{H}_{6}$ in the presence of $\mathrm{O}_{2}$ over $\mathrm{Ag} / \mathrm{Al}_{2} \mathrm{O}_{3}$ catalyst: Role of surface nitrate species. Phys. Chem. Chem. Phys. 2000, 2 (3), 367-372.

(43) Bayer, G.; Wiedemann, H. G. Formation, dissociation and expansion behavior of platinum group metal oxides $\left(\mathrm{PdO}, \mathrm{RuO}_{2}\right.$, $\mathrm{IrO}_{2}$ ). Thermochim. Acta 1975, 11 (1), 79-88.

(44) Park, K.-T.; Novikov, D. L.; Gubanov, V. A.; Freeman, A. J. Electronic structure of noble-metal monoxides: $\mathrm{PdO}, \mathrm{PtO}$, and $\mathrm{AgO}$. Phys. Rev. B: Condens. Matter Mater. Phys. 1994, 49 (7), 4425-4431.

(45) Goguet, A.; Aouine, M.; Cadete Santos Aires, F. J.; De Mallmann, A.; Schweich, D.; Candy, J. P. Preparation of a $\mathrm{Pt} / \mathrm{SiO}_{2}$ Catalyst: I. Interaction between Platinum Tetrammine Hydroxide and the Silica Surface. J. Catal. 2002, 209 (1), 135-144.

(46) Sietsma, J. R. A.; Meeldijk, J. D.; den Breejen, J. P.; VersluijsHelder, M.; van Dillen, A. J.; de Jongh, P. E.; de Jong, K. P. The Preparation of Supported $\mathrm{NiO}$ and $\mathrm{Co}_{3} \mathrm{O}_{4}$ Nanoparticles by the Nitric Oxide Controlled Thermal Decomposition of Nitrates. Angew. Chem., Int. Ed. 2007, 46 (24), 4547-4549.

(47) Sietsma, J. R. A.; Friedrich, H.; Broersma, A.; Versluijs-Helder, M.; Jos van Dillen, A.; de Jongh, P. E.; de Jong, K. P. How nitric oxide affects the decomposition of supported nickel nitrate to arrive at highly dispersed catalysts. J. Catal. 2008, 260 (2), 227-235. 